\author{
Магдалюк О.В. \\ аспірант \\ кафедра фрінансів, банківської справи та страхування \\ Університет банківської справи \\ вул. Андріївська, 1, м. Київ, Україна, 04070 \\ E-mail: mahdaluk@ukr.net \\ ORCID ID: 0000-0002-4336-1899
}

\title{
УПРАВЛІНСЬКІ АСПЕКТИ ФІНАНСОВИХ МОДЕЛЕЙ ФОРМУВАННЯ ТА ЗРОСТАННЯ ВАРТОСТІ КАПІТАЛУ ПІДПРИЄМСТВА
}

Вартісна проблематика дослідження капіталу підприємства $€$ однією з найбільш популяризованих у сучасних фінансово-економічних публікаціях. Це пояснюється тим, що здатність капіталу як вартості формувати додану вартість $€$ його іманентною властивістю. Розглядаючи підприємство як форму організації капіталу, науковці та практики фокусуються переважно на його об'єктному аспекті, що пов'язаний із дослідженням його вартісних характеристик з точки зору потенційного об'єкту інтересу для інвесторів. Узагальнюючи результати критичного аналізу управлінських аспектів базових фрінансових моделей формування та зростання вартості капіталу можна зробити наступні висновки, що більшість дослідників пов'язують вартість капіталу з факторами формування фундаментальної вартості капіталу, а також з процесами забезпечення її зростання. Визначено, що основними напрямами визначення вартості капіталу $є$ аналітичні фракторні моделі вартості капіталу, які умовно можна розподілити на моно- та полікритеріальні, які, досліджують пріоритетність одного фактору/аспекту впливу на вартість, та такі що визначають вартість як результат взаємодії певних факторів/аспектів.

Ключові слова: вартість, капітал, методи, фракторні моделі, додана вартість, прибуток, розрахунок, витрати, доходи.

This work is licensed under a Creative Commons Attribution 4.0 International License http://creativecommons.org/licenses/by/4.0/

Постановка проблеми та її зв'язок з важливими науковими та практичними завданнями. Вартісна проблематика дослідження капіталу підприємства $є$ однією з найбільш популяризованих у сучасних фінансово-економічних публікаціях. Це пояснюється тим, що здатність капіталу як вартості формувати додану вартість $\epsilon$ його іманентною властивістю. Розглядаючи підприємство як форму організації капіталу, науковці та практики фокусуються переважно на його об'єктному аспекті, що пов'язаний із дослідженням його вартісних характеристик з точки зору потенційного об'єкту інтересу для інвесторів. При цьому суб'єктна характеристика капіталу, 3 точки зору здатності формувати вартість, $є$ не менш важливою та потребує досліджень у єдності взаємозв'язку із об'єктними характеристиками, що формує цілісне уявлення про управлінську природу капіталу.

Аналіз останніх досліджень по проблемі. Дослідженню питань визначення та оцінювання капіталу підприємств присвячено наукові праці зарубіжних (Г. Арнольда, Ю. Брігхема та Л. Гапенски, Р. Брейлі та С. Майерса, І. Бланка, Д. Волкова, А. Дамодарана, I. Івашковської, М. Кудіної, Дж. Ван Хорна, А. Раппапорта ін) та вітчизняних (O. БутнікСіверського, В. Буханця, А. Гейдор, О. Мендрула, К.
Рябикіної, Л. Фролової, Г. Швиданенко, Н. Шевчук, ін.) вчених економістів. Розвиток фінансових моделей оцінювання формування та зростання вартості капіталу підприємств представлено у дослідженнях Д. Волкова, І. Івашковської, В. Когденко, М. Кудіної, К. Рябикіної, Т. Теплової, Н. Шевчук, ін.

Формулювання цілей дослідження. Метою дослідження є упорядкування змісту фінансових моделей формування та зростання вартості капіталу підприємства, визначення їх особливостей, які дозволять формувати відповідну бізнес-аналітику, яка $\epsilon$ основою прийняття фінансових управлінських рішень у сфері капіталоутворення.

У ході дослідження використано загальнонаукові та спеціальні методи наукового пізнання, що зумовлено поставленою метою. Для отримання наукових результатів було використано такі методи: бібліографічного аналізу - для впорядкування наукових позицій щодо аналітичної факторної інтерпретації вартості капіталу підприємств; наукового узагальнення - при систематизації методичних підходів до факторної інтерпретації вартості капіталу підприємств; метод причинно-наслідкових зв'язків - при впорядкуванні та визначенні управлінських аспектів фінансових моделей формування та зростання вартості капіталу підприємств. 
Інформаційною базою дослідження стали монографії, збірники наукових праць, ресурси мережі Інтернет, а також результати власних досліджень авторів.

Виклад основних результатів та їх обгрунтування. Фінансові аспекти формування та забезпечення зростання вартості у наукових дослідженнях традиційно розглядають на основі їі факторної інтерпретації, а управлінський фокус концентрується на таких вартість-формуючих факторах/аспектах, які забезпечують зростання вартості та, відповідно, стають об'єктами потенційного впливу. Так, система взаємопов'язаних факторів вартості капіталу, що визначено А. Раппапортом [1] має відношення до операційної, інвестиційної та фінансової діяльності компанії та представлена такими: темп зростання обсягів реалізації; операційна маржа; ставка податку на прибуток; інвестиції у робочий капітал; інвестиції у необоротні активи; витрати на капітал; тривалість прогнозного періоду. Так як кожний з визначених факторів може неоднозначно впливати на зміни вартості капіталу, вчений наголошує на доцільності їх оцінювання та управління у єдності взаємозв'язку.

У факторній моделі вартості капіталу Г. Арнольда [2] основний акцент зроблено на спреді доходності капіталу, а різниця із факторною моделлю А. Раппапорта полягає у тому, що фактично об'єднуються у один фактор величини капіталу такі фактори як потреби у фінансуванні оборотних та капітальних активів; рентабельність капіталу об'єднує у собі показники обсягів реалізації, операційного прибутку та ставки оподаткування прибутку.

Модель формування вартості капіталу Ю. Брігхема змістовно представляє собою взаємозв'язок двох факторів - інвестованого капіталу та доданої вартості, яка формується у результаті процесів руху капіталу, а логіка модифікованого підходу автора розкривається в аспекті достатності прибутковості капіталу для покриття витрат на капітал. Факторну модель вартості капіталу А. Дамодарана науковці визначають як фундаментальну та таку, що базується на концепції дисконтування грошових потоків, а пріоритетними факторами формування вартості у даній моделі $є$ [3]:

- $\quad$ грошові потоки, що генерують функціонуючі активи;

- очікуваний темп зростання грошових потоків, який формується за рахунок реінвестування частини чистого прибутку або зміни віддачі інвестованого капіталу;

- $\quad$ тривалість періоду перманентного зростання грошових потоків; рівень операційного та фінансового ризиків (зміни операційного ризику інвестованого капіталу, зміни пропорцій боргового фінансування або умов залучення боргових зобов'язань).

Основними обмеженнями даної моделі науковці та практики відзначають неоднозначності методичного плану, які стосуються розрахунку грошових потоків; оцінювання темпів зростання на основі методів екстраполяції може недооцінювати перспекти- ви, які є особливо характерними для інноваційноорієнтованих підприємств; експертна оцінка темпів зростання може бути недоступною для учасників ринку та відсутніми є гарантії, що ринок відреагує на зроблений прогноз.

Свого подальшого розвитку базові ідеї факторної інтерпретації вартості А. Дамодарана набули у дослідженнях І. Сгєрєва та С. Мордашова. Так, підхід C. Мордашова [4] побудовано на оцінці чутливості змін грошового потоку, до основних факторів, що його формують, а результатом реалізації такого підходу $є$ контроль змін вартості за результатами операційної, інвестиційної та фінансової діяльності. Основою факторної інтерпретації вартості І. Сгєрєва [5] $є$ системний аналіз організації та кількісне оцінювання впливу фундаментальних факторів різних рівнів ієрархії на вартість бізнесу. Не зважаючи на змістовність даних підходів, їх реалізація є досить трудомістким процесом, на чому наголошують практики.

Факторний підхід до аналізу формування вартості за Т. Коуплендом, Т. Колером, Дж. Муріном, А. Долгоффом $[6,7]$ передбачає оцінювання поточної та очікуваної вартості бізнесу, на основі прогнозованих грошових потоків, а метою управління $є$ мінімізація розриву (відхилення) між потенційною та очікуваною вартістю.

Модифікованого вигляду описані вище факторні моделі набули у концепції ключових факторів вартості (KVDM, The Key-Value-Driver Model), A. Брейлі та С. Майерса [8]. До основних факторів, які безпосередньо впливають на формування вартості автори віднесли: чистий операційний прибуток, зменшений на скореговану величину податків, віддачу від інвестованого капіталу, середньозважені витрати на капітал та темп зростання бізнесу. Ідея авторів базується на інтегруванні визначених факторів в єдиний механізм, реалізація якого зумовлює їх активізацію для забезпечення зростання фундаментальної вартості компанії.

У дослідженнях науковців пострадянського простору набув розвитку сценарно-імовірнісний підхід до факторного оцінювання зростання вартості підприємств. Так, зміст підходу І. Івашковської [9] полягає у формулюванні можливих сценаріїв розвитку підприємства, їх оцифровці та перекладі на мову конкретних вартість-формуючих показників, що в подальшому $є$ основою оцінювання, формування та вибору стратегії підприємства. Підхід Ю. Козиря [10] базується на ситуаційному моделюванні вартості при оцінці альтернатив розвитку підприємства. Науковець визначив вартісні критерії прийняття інвестиційних рішень на основі вибору між: інвестуванням в активи та погашенням зобов'язань; інвестуванням в активи та виплатою дивідендів; інвестуванням в активи та залишком запасу грошових коштів; купівлею (продажем) та орендою нерухомості. Підхід С. Валдайцева [11] базується на аналізі інноваційно-інвестиційних факторів формування вартості, а Н. Синявський [12] основний акцент зробив на моделюванні грошових потоків і визначенні величини майбутньої вартості майна підприємства в залежності від прийняття нових технічних та органі- 
заційних рішень. О. Мендрулом [13] запропоновано здійснювати аналіз вартості на основі визначення ступеню підпорядкованості факторів, спрямованості їх дії та силі впливу на формування вартості. Пропонована вченим типололгізація факторів, а також виокремлення їх класифікаційних ознак (характер і спосіб впливу на вартість, можливість контролю, спрямованість і термін дії, місце прояву, характер інновацій, оціненість ринком) дозволяють сфокусуватися на ключових параметрах управління, які визначаються як інтереси зацікавлених осіб, час, фактори виробництва, ризик, та обгрунтувати методологічні підходи до виявлення сутнісних характеристик поточного та антикризового управління вартістю підприємств [13]. У наукових дослідженнях Л. Фролової [14], О. Лісніченко [14], К. Рябикіної [15], Н. Шевчук [16] визначено ресурсні фактори формування вартості, цілеспрямований вплив на які дозволяє забезпечити очікувані зміни доданої вартості підприємства.

Ще одним напрямком факторного оцінювання вартості капіталу підприємства, що активно розвивається в межах теорії корпоративного зростання бізнесу є моделі вартісного зростання. Так, у моделі С. Pосса [17] внутрішне вартісне зростання бізнесу забезпечується у площині оптимізації структури капіталу та можливостей підтримки значного систематичного обсягу інвестування. В основі забезпечення стійкого зростання вартості підприємства І. Івашковська [18] закладає інтегровані ключові фактори, які виконують роль інструментарію стратегічного та операційного контролю, що визначаються, відповідно, темпами зростання сукупного капіталу та кількістю років, протягом яких спред доходності реалізації був позитивною величиною (стратегічний контроль) $\mathrm{i}$ спредом рентабельності реалізації, який враховує якість управління витратами при заданих темпах зростання обсягів продажу (операційний контроль). Відповідно до моделі вартісного зростання, що представлено у дослідженнях Н. Шевчук [19] основний акцент зроблено на розмежуванні факторів формування вартості (спреді доходності реалізації продукції) та їі зростання (продуктивності та величині капіталу).

Висновки та перспективи подалыших досліджень. Узагальнюючи результати критичного аналізу управлінських аспектів базових фінансових моделей формування та зростання вартості капіталу можна зробити такі змістовні узагальнення:

1) особливістю представлених аналітичних моделей $є$ те, що дослідники зазвичай або не конкретизують вид вартості, факторний аналіз якої здійснюється, або наголошують на тому, що це $є$ іiі ринкові оцінки, тобто ринкова вартість. При цьому, якщо проаналізувати перелік вартість-формуючих факторів, на якому дослідники роблять акцент незалежно від змісту моделі, то їх переважна більшість $\epsilon$ внутрішніми, тобто такими, що підконтрольні менеджменту підприємства. Тобто, фактично, дослідники фокусуютья на факторах формування фундаментальної вартості капіталу. Подальша позиція авторів буде базуватися на залежностіІспіввідношенні між ринковою та фундаментальною вартістю як критеріїв ефективності управління капіта- лом підприємства виходячи із логіки, яка формалізована такими рівняннями (формулами $1-3)$ [21].

$$
\begin{gathered}
\text { Val }_{\text {mark }}=\text { Val }_{\text {bal }}+\text { Val }_{\text {add }}+\text { Val }_{\text {gap }} \\
\text { Val }_{\text {fund }}=\text { Val }_{\text {bal }}+\text { Val }_{\text {add }} \\
\text { Val }_{\text {mark }}=\text { Val }_{\text {fund }}+\text { Val }_{\text {gap }}
\end{gathered}
$$

де Val $_{\text {mark }}$ - ринкова вартість капіталу підприємства, гр.од; тва, гр.од;

$V_{a l} l_{b a l}$ - балансова вартість капіталу підприємс-

$V a l_{a d d}$ - додана вартість капіталу підприємства, гр.од;

Val $_{\text {gap }}$ - розрив між фундаментальною та ринковою вартістю капіталу підприємства, гр.од;

$V_{\text {alund }}$ - фундаментальна вартість капіталу підприємства, гр.од.

Дані співвідношення можуть слугувати основою для обгрунтування вибору пріоритетних напрямків управлінського впливу та адекватної моделі організаційної поведінки $з$ потенційними фінансовими стейкхолдерами, що буде формалізовано та представлено далі у змістовних межах наукового дослідження;

2) відповідно до переважної більшості аналітичних факторних моделей вартості капіталу об'єктом управлінського фокусування виступають процеси забезпечення iї зростання, при цьому проблематика формування вартості залишається поза межами досліджень. 3 точки зору ефективності управління капіталом за критерієм фундаментальної вартості питання їі формування (відповідно до системи рівнянь це балансова $\left(V_{a l}\right)$ та додана вартість $\left.\left(V a l_{a d d}\right)\right)$ стають ключовими, так як про зростання вартості у довгостроковій перспективі мова може йти лише тоді, коли функціонуючий капітал здатний формувати, а не руйнувати вартість. У такій змістовній постановці актуалізується питання про пріоритетність капітальних факторів формування фундаментальної вартості, які традиційно розглядаються або в аспекті рівнів цілеспрямованого впливу на капітал (операційний, фінансовий, стратегічний); за видами капіталу («капітальні активи ↔ оборотні активи»; інвестований капітал, балансовий капітал, ін.); за видами носіїв різних форм капіталу (фінансові, стратегічні стейкхолдери). Цілком підтримуючи дані підходи, вважаємо, що вони потребують розвитку з урахуванням постіндустріальних тенденцій розвитку, які зміщують акцент із видової форми прояву капіталу як такого на результати взаємодії та взаємовідносин між диференційованими видами капіталу;

3) аналітичні факторні моделі вартості капіталу умовно можна розподілити на моно- та полікритеріальні, тобто такі, що досліджують пріоритетність одного фактору/аспекту впливу на вартість, та такі що визначають вартість як результат взаємодії певних факторів/аспектів. Розуміючи дослідницьку цінність монокритеріальних моделей, варто наголосити на 
тому, що за сучасних умов діяльності, навіть полікритеріальні аналітичні моделі набувають змін 3 точки зору використання. Так, факторна інтерпретація моделей вартості набуває змісту не тільки на основі фо- рмалізації капітальних залежностей у строго математичній формі, а актуалізується потреба у побудові більш складних каузальних аналітичних конструкцій на основі використання змішаної системи показників.

\section{Література}

1. Rappaport A. Creating Shareholder Value: A Guide for Managers and Investors. Free Press, 1997. 224 p.

2. Арнольд Г. Руководство по корпоративным финансам: Пособие по финансовым рынкам, решениям и методам. Днепропетровск: Баланс Бизнес Букс, 2007. 752 с

3. Damodaran A. Investment Valuation: Tools and Techniques for Determining the Value of Any Asset. John Wiley \& Sons, 1995. 837 p.

4. Мордашов С. Рычаги управления стоимостью компании. Рынок ценных бумаг. 2001. № 15. С. 51-55. doi: 10.1080/09528820108576914

5. Егерев И.А. Стоимость бизнеса: Искусство управления: учеб. пособие. М.: Дело, 2003. 465 с

6. Коупленд Т. Стоимость компании: оценка и управление / Коупленд Т.; пер. с англ. Я. Барышникова. 3 е изд., перераб. и доп. М.: Олимп-Бизнес, 2005. 576 с.

7. Коупленд Т. Expections-Based Management. Как достичь превосходства в управлении стоимостью компании / Коупленд Т.; пер. с англ. Э.В.Кондуковой. М.: Эксмо, 2009. 384 с.

8. Брейли Р. Принципы корпоративных финансов. М.: Олимп-Бизнес, 2012. 978 с.

9. Ивашковская И.В. Финансовые измерения корпоративных стратегий. Стейкхолдерский подход: монография. М.: ИНФРА-М, 2008. 319 с.

10. Козырь Ю.В. Оценка и управление стоимостью имущества промышденного предприятия : автореф. дис. ... канд. экон. наук : спец. 08.00.05: захист: 26.05.2003 / наук. керівник Н. А. Мильчакова.М.: 2003.24 с.

11. Валдайцев С. В. Оценка бизнеса и управление стоимостью предприятия. М.: Юнити-Дана, 2002. 720

c.

12. Синявский Н.Г. Оценка бизнеса: гипотезы, инструментарий, практические решения в различных областях деятельности. М.: Финансы и статистика, 2005. 240 с.

13. Мендрул О.Г. Управління вартістю підприємств: монографія. К.: КНЕУ, 2002. 272 с.

14. Фролова Л.В. Управління вартістю підприємства: монографія. Кривий Ріг: 2015. 290 с

15. Рябикіна К. Г. Ефективність управління капіталом підприємств: монографія. Кривий Ріг : Видавництво «Діонат» (ФО-П Чернявський Д.О.), 2019. 200 с.

16. Шевчук Н.В. Багатофакторна модель оцінювання фундаментальної вартості національних підприємств чорної металургії. Стратегія підприємства: зміна парадигми управління та інноваційні рішення для бізнесу: колективна монографія / за ред.. проф. А.П. Наливайка. К.: КНЕУ, 2015. 398 с., С. 282 - 296

17. Ross S. A. Westerfield R. W., Jordan B. D. Fundamentals of Corporate Finance, 5 ed. McGrow-Hill, 2000. $102 \mathrm{p}$

18. Пономаренко Т.В. Корпоративный рост горных компаний: сущность, факторы и методические подходы к оценке. Корпоративное управление и инновационное развитие экономики Севера. 2014. № 3. URL: http://vestnik-ku.ru/images/2014/3/2014-3-12.pdf (дата звернення 15 січня 2020 р.)

19. Ивашковская И.В. Устойчивый рост компании: финансовый подход. Российское предпринимательство. 2008. № 3 Вып (1). С. 100 - 104. doi: 10.1002/j.1551-8833.2008.tb08114.x

20. Шевчук Н.В. Економічне зростання національних промислових підприємств: вартісно-орієнтований аспект. Соціально-економічний та технічний розвиток підприємств: проблеми, рішення, оцінка ефективності : монографія / за ред. Л.М. Савчук. Дніпропетровськ: Національна металургійна академія, Пороги, 2016.554 с., C. $193-204$

21. Shevchuk N., Bortnik A. The strategy-oriented aspects of enterprise capitalization. Modern Science Moderní véda. 2019. № 2. P. 70 - 78.

Магдалюк А.B. аспирант

кафедра финансов, банковского дела и страхования

Университет банковского дела

ул. Андреевская, 1, г. Киев, Украина, 04070

E-mail: mahdaluk@ukr.net

ORCID ID: 0000-0002-4336-1899

\section{УПРАВЛЕНЧЕСКИЕ АСПЕКТЫ ФИНАНСОВЫХ МОДЕЛЕЙ ФОРМИРОВАНИЯ И РОСТА СТОИМОСТИ КАПИТАЛА ПРЕДПРИЯТИЯ}

Стоимостная проблематика исследования капитала предприятия является одной из наиболее популяризированных в современных финансово-экономических публикациях, объясняется тем, что 
способность капитала как стоимости формировать добавленную стоимость является его имманентным свойством. Рассматривая предприятие как форму организации капитала, ученые и практики фокусируются преимущественно на его объектном аспекте, который связан с исследованием его стоимостных характеристик с точки зрения потенциального объекта интереса для инвесторов. Финансовые аспекты формирования и обеспечения роста стоимости в научных исследованиях традиционно рассматривается на основе ее факторной интерпретации, а управленческий фокус концентрируется на таких стоимость-формирующих факторах/аспектах, которые обеспечивают рост стоимости и, соответственно, становятся объектами потенциального воздействия. В работах зарубежных и отечественных ученых стоимость капитала рассматривалось в факторной модели, которая имела разные подходы к оценке. Так в одних работах, стоимость капитала рассматривалась с позиции отношения к операционной, инвестиционной и финансовой деятельности компании, в других работах - инвестированного капитала и добавленной стоимости, которая фрормируется в результате процессов движения капитала, а логика модифицированного подхода автора раскрывается в аспекте достаточности доходности капитала для покрытия затрат на капитал.

Обобщая результаты критического анализа управленческих аспектов базовых фринансовых моделей формирования и роста стоимости капитала можно сделать следующие выводы, что большинство исследователей связывают стоимость капитала с фракторами формирования фундаментальной стоимости капитала, а также с процессами обеспечения ее роста. Определено, что основными направлениями определения стоимости капитала являются аналитические факторные модели стоимости капитала, которые условно можно разделить на моно - и поликритериальные, которые, исследуют приоритетность одного фактора/аспекта влияния на стоимость, и такие определяющие стоимость как результат взаимодействия определенных факторов/аспектов.

Ключевые слова: стоимость, капитал, методы, модели, добавленная стоимость, прибыль, расчет, расходы, доходы.

\author{
Magdalyuk A. \\ Postgraduate student \\ Department of Finance, Banking and Insurance \\ University of Banking \\ str. Andriivska, 1, r. Kyiv, Ukraine, 04070 \\ E-mail: mahdaluk@ukr.net \\ ORCID ID: 0000-0002-4336-1899
}

\title{
MANAGERIAL ASPECTS OF FINANCIAL MODELS FOR THE FORMATION AND GROWTH OF COST OF THE COMPANY'S CAPITAL
}

Cost issues of the study of the company's capital is one of the most popularized topics in the modern financial and economic publications, due to the fact that the ability of capital as cost to form of the added value is its immanent property. Considering the enterprise as a form of capital organization, academics and practitioners focus mainly on the aspect of its object, which is associated with the study of its cost characteristics from the point of view of a potential object of interest for investors. Financial aspects of formation and providing of growth of value in scientific research are traditionally considered on the basis of its factor interpretation, and managerial focus is concentrated on such price-forming factors/aspects that provide growth in the value and, consequently, become objects of potential impacts. In the works of foreign and domestic scientists the cost of capital was considered in factory model, which had different approaches to assessment. So in some works, the cost of capital was considered from a position of relationship to operating, investment and financial activities of the company, in other works from the position of invested capital and added value, which is the result of processes of capital flow, and the logic of the modified approach of the author is revealed in the aspect of adequacy of return on capital to cover the cost of capital.

Summarizing the results of a critical analysis of managerial aspects of basic financial models of the formation and growth of cost of capital we can make the following conclusions that the majority of researchers associate the cost of capital with the factors of formation of the fundamental value of capital as well as processes to ensure its growth. It has been determined that the main areas of determining the cost of capital are analytical factor models of the cost of capital, which can be divided into mono - and poly criteria-based models, which examine the priority of one factor/aspect impact on the cost, and such cost determining models which define cost as a result of the interaction of certain factors/aspects.

Key words: cost, capital, methods, models, value added, profit, payment, expense, income. 


\section{References}

1. Rappaport, A. (1997). Creating Shareholder Value: A Guide for Managers and Investors. Free Press.

2. Arnold, G. (2007). Rukovodstvo po korporativnyim finansam: Posobie po finansovyim ryinkam, resheniyam i metodam. Dnepropetrovsk: Balans Biznes Buks.

3. Damodaran, A. (1995). Investment Valuation: Tools and Techniques for Determining the Value of Any Asset. John Wiley \& Sons.

4. Mordashov, S. (2001). Ryichagi upravleniya stoimostyu kompanii. Ryinok tsennyih bumag, (15), 51-55. doi: 10.1080/09528820108576914

5. Egerev, I. A. (2003). Stoimost biznesa: Iskusstvo upravleniya. Moscow: Delo.

6. Kouplend, T. (2005). Stoimost kompanii: otsenka i upravlenie. (Ya. Baryishnikova, Trans.). (3rd. ed.). Moscow: Olimp-Biznes.

7. Kouplend, T. (2009). Expections-Based Management. Kak dostich prevoshodstva v upravlenii stoimostyu kompanii. (E. V. Kondukova, Trans.). Moscow: Eksmo.

8. Breyli, R. (2012). Printsipyi korporativnyih finansov. Moscow: Olimp-Biznes.

9. Ivashkovskaya, I. V. (2008). Finansovyie izmereniya korporativnyih strategiy. Steykholderskiy podhod. Moscow: INFRA-M.

10. Kozyir, Yu. V. (2003). Otsenka i upravlenie stoimostyu imuschestva promyishdennogo predpriyatiya. [Doctoral dissertation abstract: 08.00.05]. Moscow.

11. Valdaytsev, S. V. (2002). Otsenka biznesa i upravlenie stoimostyu predpriyatiya. Moscow: Yuniti-Dana.

12. Sinyavskiy, N. G. (2005). Otsenka biznesa: gipotezyi, instrumentariy, prakticheskie resheniya $v$ razlichnyih oblastyah deyatelnosti. Moscow: Finansyi i statistika.

13. Mendrul, O. H. (2005). Upravlinnia vartistiu pidpryiemstv. Kyiv: KNEU.

14. Frolova, L. V. (2015). Upravlinnia vartistiu pidpryiemstva. Kryvyi Rih.

15. Riabykina, K. H. (2019). Efektyvnist upravlinnia kapitalom pidpryiemstv. Kryvyi Rih: Vydavnytstvo «Dionat» (FO-P Cherniavskyi D. O.).

16. Shevchuk, N. V. (2015). Bahatofaktorna model otsiniuvannia fundamentalnoi vartosti natsionalnykh pidpryiemstv chornoi metalurhii. In A. P. Nalyvaika (Ed.), Stratehiia pidpryiemstva: zmina paradyhmy upravlinnia ta innovatsiini rishennia dlia biznesu (pp. 282-296). Kyiv: KNEU.

McGrow-Hill.

17. Ross, S. A., Westerfield, R. W., \& Jordan, B. D. (2000). Fundamentals of Corporate Finance. (5th ed.).

18. Ponomarenko, T. V. (2014). Korporativnyiy rost gornyih kompaniy: suschnost, faktoryi i metodicheskie podhodyi k otsenke. Korporativnoe upravlenie i innovatsionnoe razvitie ekonomiki Severa, (3). Retrieved January 15 , 2020, from http://vestnik-ku.ru/images/2014/3/2014-3-12.pdf

19. Ivashkovskaya, I. V. (2008). Ustoychivyiy rost kompanii: finansovyiy podhod. Rossiyskoe predprinimatelstvo, (3 (1)), 100 - 104. doi: 10.1002/j.1551-8833.2008.tb08114.x

20. Shevchuk, N. V. (2016). Ekonomichne zrostannia natsionalnykh promyslovykh pidpryiemstv: vartisnooriientovanyi aspekt. In L. M. Savchuk (Ed.), Sotsialno-ekonomichnyi ta tekhnichnyi rozvytok pidpryiemstv: problemy, rishennia, otsinka efektyvnosti (pp. 193-204). Dnipropetrovsk: Natsionalna metalurhiina akademiia, Porohy.

21. Shevchuk, N., \& Bortnik A. (2019). The strategy-oriented aspects of enterprise capitalization. Modern Science-Moderní věda, (2), $70-78$.

Received 10 May 2020

Approved 24 May2020

Available in Internet 11.07.2020

Цитування згідно ДСТУ 8302:2015

Магдалюк О.В. Управлінські аспекти фінансових моделей формування та зростання вартості капіталу підприємства // Економіка харчової промисловості. 2020. Т.12, вип. 2. С. 76-81. doi: 10.15673/fie.v12i2.1743

Cite as APA style citation

Magdalyuk, A. (2020). Managerial aspects of financial models for the formation and growth of cost of the company's capital. Food Industry Economics, 12(2), 76-81. doi: 10.15673/fie.v12i2.1743 